\title{
Decreased Formation of Inositol Trisphosphate in Madin-Darby Canine Kidney Cells under Conditions of $\beta$-Glucosidase Inhibition'
}

\author{
Shahryar Mahdiyoun,* Gayatri D. Deshmukh,* Akira Abe, $\dagger$ \\ Norman S. Radin, $†$ and James A. Shayman*,2 \\ ${ }^{*}$ Department of Internal Medicine, and $\nmid$ Mental Health Research Institute, University of Michigan \\ Medical Center, Ann Arbor, Michigan 48109-0676
}

Received July 24,1991 , and in revised form October 4, 1991

\begin{abstract}
Recent work has demonstrated the enhancement of hormone-stimulated inositol trisphosphate formation in renal epithelial cells under conditions of glucosylceramide depletion. The role of glucosylceramide metabolism was explored further by exposing Madin-Darby canine kidney (MDCK) cells to the $\beta$-glucosidase inhibitor conduritol $B$ epoxide, which produced time-dependent and concentration-dependent increases in glucosylceramide levels and decreased bradykinin-stimulated inositol trisphosphate formation from isolated MDCK cell membranes. These data provide further support for an association between glucosylceramide levels and hormone-stimulated inositol trisphosphate formation. 1992 Academic Press, Inc.
\end{abstract}

Glycosphingolipids are membrane components that are composed of a long chain sphingoid amine (a sphingol), a fatty acid, and a carbohydrate. The hydrophobic moiety, ceramide, consists of the sphingol substituted at the amino group by a fatty acid in amide linkage. The carbohydrate moiety is linked at the primary hydroxyl group of the sphingol in a glycosidic linkage. GlcCer is the most widely distributed glycolipid; it serves as the base for over 200 known glucosphingolipids. It is formed by ceramide:UDPglucose glucosyltransferase, which can be inhibited by the GlcCer analogue D-threo-PDMP ${ }^{3}(1-4)$. GlcCer is de-

\footnotetext{
${ }^{1}$ This work was supported by National Institutes of Health Grants RO1 DK41487 (J.A.S.) and NS03192-32 (N.S.R.) and a Merit Review Research Award from the Veterans Administration (J.A.S.). N.S.R. is a Senator Jacob Javits Investigator Awardee.

${ }^{2}$ To whom correspondence should be addressed.

${ }^{3}$ Abbreviations used: GlcCer, glucosylceramide; CBE, conduritol B epoxide; C:M:W, chloroform:methanol:water $(\mathrm{v} / \mathrm{v} / \mathrm{v}$, in solvent mixtures); InsP3, myo inositol 1,4,5 trisphosphate; PDMP, threo-1-phenyl
}

graded by a $\beta$-glucosidase that is inhibitable by CBE ( 5 , 6). Recently we reported that depletion of GlcCer by exposure of MDCK cells to PDMP resulted in a significant potentiation of hormone-stimulated InsP3 formation in both intact MDCK cells and isolated plasma membrane of these cells (4). This effect was reversed by exposure of cells to exogenously added GlcCer. We now report that an increase in endogenous GlcCer in MDCK cells results in a significant decrease in hormone-stimulated InsP3 formation. This observation provides further support for the hypothesis that GlcCer or a GlcCer metabolite modulates the hydrolysis of phosphatidylinositol bisphosphate.

\section{MATERIALS AND METHODS}

Materials. PDMP and CBE were synthesized as previously described $(7,8) \cdot\left[6-{ }^{3} \mathrm{H}\right]$ Galactose $(30 \mathrm{Ci} / \mathrm{mmol}),\left[9,10(\mathrm{n})-{ }^{3} \mathrm{H}\right]$ palmitate $(52 \mathrm{Ci} / \mathrm{mol})$, and $m y o-\left[2-{ }^{3} \mathrm{H}\right]$ inositol $1,4,5$-trisphosphate $(45 \mathrm{Ci} / \mathrm{mmol})$ were from Amersham (Arlington Heights, IL). Glucosylceramide was isolated from the spleen of a patient with Gaucher disease (9). Galactosylceramide from bovine brain was from Serdary (Port Huron, MI). MDCK cells were from the American Type Culture Collection (CCL-34, Rockville, MD). Bradykinin was from Sigma Chemical Co. (St. Louis, MO), guanosine-5'-O-(3-thiotriphosphate) (GTP $\gamma \mathrm{S})$ was from Boehringer Mannheim Biochemicals (Indianapolis, IN), and ganglioside standards were from Matreya, Inc. (Pleasant Gap, PA).

Glycosphingolipid extraction and isolation. MDCK cells $\left(5 \times 10^{5}\right)$ were grown in $57-\mathrm{cm}^{2}$ flasks in defined (serum-free) medium according to the formulation of Taub $(10) .\left[{ }^{3} \mathrm{H}\right]$ Galactose $(5 \mu \mathrm{Ci} / \mathrm{ml})$ or $\left[{ }^{3} \mathrm{H}\right]$ palmitate $(5 \mu \mathrm{Ci} / \mathrm{ml})$ with or without $20 \mu \mathrm{M}$ PDMP was added 24 $\mathrm{h}$ after plating. The radiolabeled compounds were added to the medium prior to filtering. Medium containing $\left[{ }^{3} \mathrm{H}\right]$ palmitate was sonicated for $10 \mathrm{~min}$ prior to filtration. After another $24 \mathrm{~h}$, the cells were scraped off the flask with a rubher policeman and extracted three times with $3 \mathrm{ml}$

2-decanoylamino-3-morpholino-1-propanol; MDCK, Madin-Darby canine kidney; EGTA, ethylene glycol bis ( $\beta$-aminoethyl ether $) N, N^{\prime}$-tetraacetic acid. 
of C:M (1:2). The pooled extracts from a single flask were evaporated to dryness. The residues were suspended in $1 \mathrm{ml}$ of $\mathrm{C}: \mathrm{M}: \mathrm{W}$ (30:60:8) and applied to a DEAE-Sephadex column $(0.44 \mathrm{~g}$ in $10 \times 1-\mathrm{cm}$ column, $\mathrm{AcO}^{-}$form, equilibrated with $\mathrm{C}: \mathrm{M}: \mathrm{W}(30: 60: 8)$. Neutral lipids were eluted with $30 \mathrm{ml}$ of the same solvent and acidic lipids were eluted with $30 \mathrm{ml}$ of C:M:0.3 M sodium acetate (30:60:8). The eluates were evaporated under nitrogen and subjected to alkaline methanolysis, by adding $3 \mathrm{ml}$ of $0.5 \mathrm{~N} \mathrm{NaOH}$ in methanol and heating for $60 \mathrm{~min}$ at $40^{\circ} \mathrm{C}$. The samples were dialyzed against tap water at $4^{\circ} \mathrm{C}$ for $24 \mathrm{~h}$ and dried in vacuo. The neutral lipid fraction was then suspended in $1 \mathrm{ml}$ of C:M (98:2) and subjected to silicic acid chromatography with $0.5 \mathrm{~g}$ of Unisil (200-325 mesh, Clarkson Chemical, Williamsport, PA). Ceramides were eluted with $35 \mathrm{ml}$ of C:M (98:2), cerebrosides were eluted with $35 \mathrm{ml}$ of C:M (80:20), and sphingomyelin was eluted with $35 \mathrm{ml}$ of C:M:W (50:50:5). The acidic lipid fraction from the DEAE-Sephadex column was also subjected to alkaline methanolysis and dialysis.

Thin layer chromatography. Samples were analyzed by high-performance thin layer chromatography $(10 \times 10 \mathrm{~cm}$ HPTLC plates from $\mathbf{E}$. Merck, Darmstadt). Galactosyl- and glucosylceramides were separated with C:M:W (65:25:4) on plates which had been developed with $2.5 \%$ borax in $\mathrm{M}: \mathrm{W}(1: 1)$ and heated at $110^{\circ} \mathrm{C}$ prior to use. The acidic glycosphingolipids were separated with $\mathrm{C}: \mathrm{M}: 0.2 \% \mathrm{CaCl}_{2}$ (60:40:9). Ceramide (isolated from $\left[{ }^{3} \mathrm{H}\right]$ palmitate-labeled cells) was developed with hexane: C (1:1) followed by C:M:HOAc (91:2:3). Sphingomyelin was separated in a solvent system utilizing C:M:W (60:35:8). Plates were exposed for $96 \mathrm{~h}$ to Kodak X-OMAT AR film following treatment with $\mathrm{En}^{3} \mathrm{Hance}$ spray. Charring was done with other plates using GlcCer standards and the copper sulfate phosphoric acid reagent (11). Cerebrosides were quantitated by densitometry using a Bio-Rad 620 videodensitometer and 2-D Analyst software.

Plasma membrane preparation. Crude plasma membranes were isolated following exposure to hypotonic buffer by the protocol of Hepler and Harden (12). Prior to the exposure to agonist, the membranes were pelleted at $12,000 \mathrm{~g}$. Protem was determined utilizing the fluorescamine reagent (13).

Inositol 1,4,5-trisphosphate determination. Hormone-stimulated InsP3 formation was measured in intact MDCK cells as previously detailed $(4,14)$. For broken cell studies, membranes were suspended in $100 \mu \mathrm{l}$ of a buffer consisting of $10 \mathrm{~mm}$ Hepes, $2 \mathrm{mM}$ EGTA, $424 \mu \mathrm{M}$ $\mathrm{CaCl}_{2}, 0.91 \mathrm{mM} \mathrm{MgSO}{ }_{4}, 115 \mathrm{mM} \mathrm{KCl}$, and $5 \mathrm{mM} \mathrm{KH}_{2} \mathrm{PO}_{4}, \mathrm{pH} 7.0$. Additions consisting of the same buffer, containing $50 \mu \mathrm{l}$ of $3.0 \mu \mathrm{M}$ GTP $\gamma \mathrm{S}$ and $0.3 \mu \mathrm{M}$ bradykinin, were made. After $15 \mathrm{~s}, 150 \mu \mathrm{l}$ of $6 \%$ trichloroacetic acid was added and the resultant precipitate was sedimented by centrifugation at $5000 \mathrm{~g}$. The supernatant was treated with trioctylamine-Freon to extract the acid. InsP3 formation was measured by a competitive binding assay utilizing high specific activity myo-[2${ }^{3} \mathrm{H}$ ]inositol 1,4,5-trisphosphate binding to calf adrenocortical microsomes (15) as recently applied for measurements in intact MDCK cells $(4,14)$.

Exogenous cerebroside incorporation. GlcCer, labeled with $\left[{ }^{3} \mathrm{H}\right]$ palmitate, was prepared as previously described (16) and studied as follows. Dioleoylphosphatidylcholine $(12.8 \mathrm{mg})$, GlcCer $(1.5 \mathrm{mg})$, and $\left[{ }^{3} \mathrm{H}\right]$ GlcCer $\left(2.71 \times 10^{6} \mathrm{cpm}\right)$ in C:M (2:1) were dried under nitrogen and suspended in $1.5 \mathrm{ml}$ of phosphate-buffered saline. The mixture was vortexed and sonicated for 20 inin using a probe sonicator. The dispersion was centrifuged for $10 \mathrm{~min}$ at $1500 \mathrm{rpm}$ and the supernatant was filtered through a $0.2-\mu \mathrm{m}$ filter.

MDCK cells were plated on a $100-\mathrm{mm}$ dish and $200 \mu \mathrm{l}$ of the liposomal preparation was added to $8 \mathrm{ml}$ of medium. After $24 \mathrm{~h}$ the medium was aspirated and the cells were washed with phosphate buffered saline. Cellular lipids from each dish were extracted with $2 \mathrm{ml}$ of hexane:isopropanol (3:2). The extract was dried under nitrogen and dissolved in $200 \mu \mathrm{l}$ of C:M (2:1). Thirteen microliters of $0.3 \mathrm{M}$ taurocholate was added to $50 \mu \mathrm{l}$ of this extract. The solution was dried and subjected to $\alpha$ galactosidase treatment (coffee hean $\alpha$-galartosidase, Sigma). Another $50 \mu \mathrm{l}$ was dried, suspended in $300 \mu \mathrm{CHCl}_{3}$, and subjected to alkaline methanolysis ( $150 \mu \mathrm{l}$ of $0.21 \mathrm{~N} \mathrm{NaOH}$ in $\mathrm{MeOH}$ ) for $60 \mathrm{~min}$. Methanolysis was stopped with the addition of $110 \mu \mathrm{l}$ of $0.34 \mathrm{M}$ acetic acid. The phases were separated by centrifugation and the lower phase was washed with an equal volume of $\mathrm{M}: \mathrm{W}(1: 1)$. The lower phase was dried and dissolved in C:M (2:1) prior to spotting on TLC.

For studies not utilizing radiolabeled cerebroside, liposomes containing dioleoylphosphatidylcholine were prepared in the same manner. The amount of GlcCer added, however, was varied with a constant amount of phosphatidylcholine to yield a final concentration as indicated under Results.

\section{RESULTS}

The comparative effects of $20 \mu \mathrm{M} \mathrm{CBE}$ and of the GlcCer synthase inhibitor, D-threo-PDMP, on GlcCer content are displayed in Fig. 1. Exposure of MDCK cells to the GlcCer synthase and $\beta$-glucosidase inhibitors resulted in a time-dependent decrease or increase in GlcCer content, respectively.

The time- and concentration-dependent effects of CBE exposure on GlcCer content (Fig. 2) were assayed by charring and videodensitometry. The GlcCer content of untreated cells, normalized for cell protein, reproducibly increased as a function of cell density even in the absence of inhibitor. Upon exposure to CBE, GlcCer content was greater at $48 \mathrm{~h}$ compared to $24 \mathrm{~h}$ at all concentrations of the glucosidase inhibitor.

Table I displays the sphingolipid profile of MDCK cells exposed to $20 \mu \mathrm{M}$ CBE for $48 \mathrm{~h}$ as determined by $\left[{ }^{3} \mathrm{H}\right]$ galactose labeling for the cerebrosides and ganglioside GM3 or $\left[{ }^{3} \mathrm{H}\right]$ palmitate for labeling for ceramide and sphingomyelin. The activity of GlcCer in the presence of inhibitor was more than twice that of control cells, showing that GlcCer undergoes metabolic turnover in these cells. Galactosylceramide and ganglioside GM3 labeling was unchanged. Small but consistent increases in sphingomyelin and ceramide labeling were consistently observed.

As previously reported, GlcCer synthase inhibition resulted in a significant increase in bradykinin-stimulated InsP3 formation from isolated MDCK cell membranes

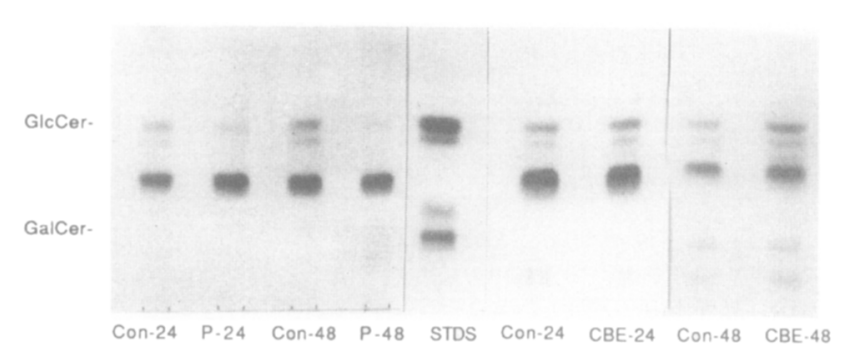

FIG. 1. Comparative effects of GlcCer synthase and $\beta$-glucosidase inhibition on GlcCer content of MDCK cells. Cells were grown for 24 or $48 \mathrm{~h}$ in the presence of either $20 \mu \mathrm{M} \mathrm{D}$-threo PDMP or CBE. After the indicated incubation periods, the cerebrosides were extracted and separated on borate-impregnated plates as described under Materials and Methods. Samples were detected by charring and compared to authentic standards. The chromatogram represents one of three independent experiments. The dark band migrating between GlcCer and GalCer represents dialkyl species of phosphatidylethanolamine. 


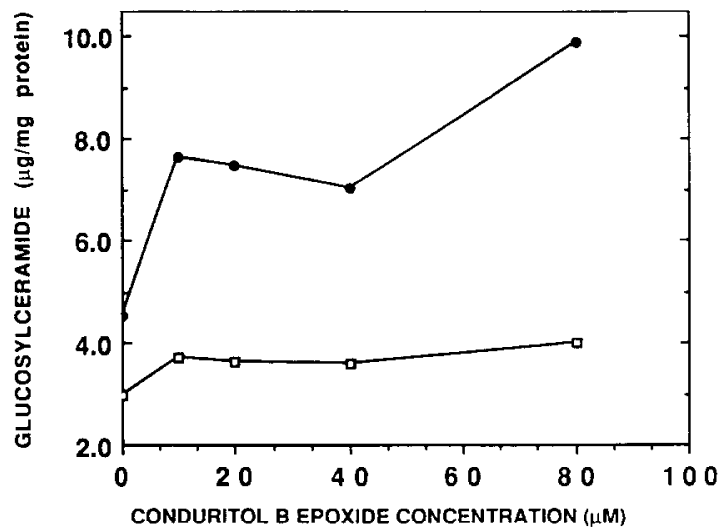

FIG. 2. Concentration-dependent changes in GlcCer content of MDCK cells following exposure to CBE. Cells were incubated for either $24 \mathrm{~h}(\square)$ or $48 \mathrm{~h}()$ in the presence of various concentrations of the $\beta$ glucosidase inhibitor. The cerebroside was quantitated by charring and densitometric detection in comparison to known weights of authentic GlcCer. Measurements were made in triplicate. The CBE data were significantly different from the control data at all concentrations of CBE.

(4). Conduritol B epoxide produced the opposite effect. The change in InsP3 formation as a function of the duration of CBE exposure is shown in Fig. 3. The slight decrement in InsP3 formation evident at $24 \mathrm{~h}$ is further enhanced by $48 \mathrm{~h}$ of exposure to the glucosidase inhibitor. This time-dependent effect occurred at a slower rate when compared to that of the GlcCer synthase inhibitor, PDMP, and probably reflects a slower rate of GlcCer degradation as compared to GlcCer synthesis in these growing cells. In addition, control cells displayed a time-dependent decrease in stimulated InsP3 formation (Fig. 3). This decrease paralleled the increase in cell-associated GlcCer under control conditions when normalized for cellular protein. A concentration-dependent effect of $\mathrm{CBE}$ on InsP3 formation was also observed (Fig. 4). This effect was maximal at $20 \mu \mathrm{M} \mathrm{CBE}$. The effect on InsP3 levels

TABLE I

Radiolabeling of Sphingolipids in Control and CBE-Exposed MDCK Cells ${ }^{a}$

\begin{tabular}{lcc}
\hline \multicolumn{1}{c}{ Lipid counted } & $\begin{array}{c}\text { Control cells } \\
\text { (cpm/ } \mu \text { g protein) }\end{array}$ & $\begin{array}{c}\text { CBE cells } \\
\text { (cpm/ } \mu \text { g protein) }\end{array}$ \\
\hline Glucosylceramide & $2.79 \pm 0.35$ & $6.58 \pm 1.98^{*}$ \\
Galactosylceramide & $0.74 \pm 0.11$ & $0.97 \pm 0.26$ \\
Ganglioside GM3 & $6.04 \pm 0.28$ & $6.04 \pm 1.28$ \\
Ceramide & $25.5 \pm 0.76$ & $31.4 \pm 0.56^{*}$ \\
Sphingomyelin & $175 \pm 4.5$ & $214 \pm 9.1$ \\
\hline
\end{tabular}

${ }^{a}$ Sphingolipid labeling was performed as described under Materials and Methods. Data represent the mean $\pm \mathrm{SE}$ of four or five independent determinations.

${ }^{*} P<0.02$ by the paired $t$ test.

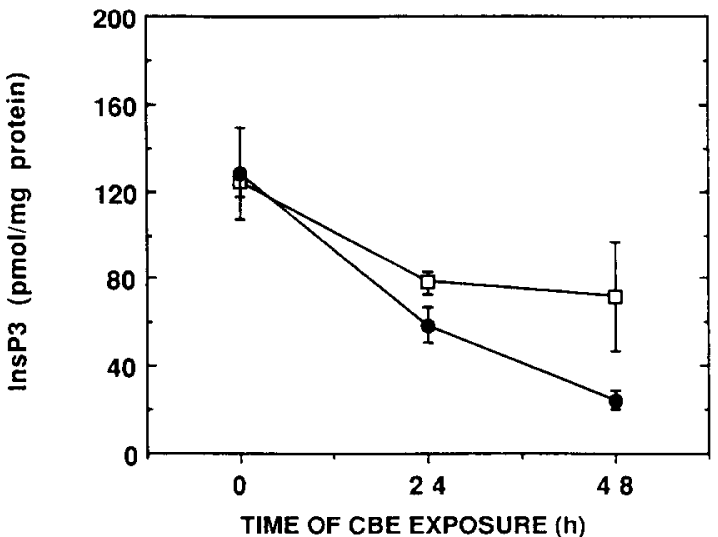

FIG. 3. InsP3 formation from MDCK cell membranes of cells exposed to CBE. MDCK cells were grown in the presence ( $\bullet$ ) or absence ( $\square$ ) of $20 \mu \mathrm{M}$ CBE for 0,24 , or $48 \mathrm{~h}$. Cell membranes were isolated and InsP3 formation in response to $10^{-7} \mathrm{M}$ bradykinin and $1 \mu \mathrm{M} \mathrm{GTP} \gamma \mathrm{S}$ was determined as described under Materials and Methods. The error bars represent $1 \mathrm{SD}$ from the mean of triplicate values.

was not the result of increased substrate levels. No difference in phosphatidylinositol bisphosphate was seen in MDCK cells treated with $20 \mu \mathrm{M}$ CBE when compared to untreated control cells $(1.34 \pm 0.23$ versus $1.25 \pm 0.17$ $\mathrm{nmol} / \mathrm{mg}$ protein).

The change in InsP3 levels associated with changes in cerebroside content may be the result of impaired formation or catabolism. The 5-phosphomonoesterase that degrades InsP3 is magnesium dependent and inhibitable by a variety of glycolytic intermediates including 2,3 -bisphosphoglycerate (17). Although no 3-kinase activity was observed in the isolated membrane preparations, a small amount of 5-phosphatase activity was observed, as evidenced by the formation of inositol 1,4-bisphosphate. 5-

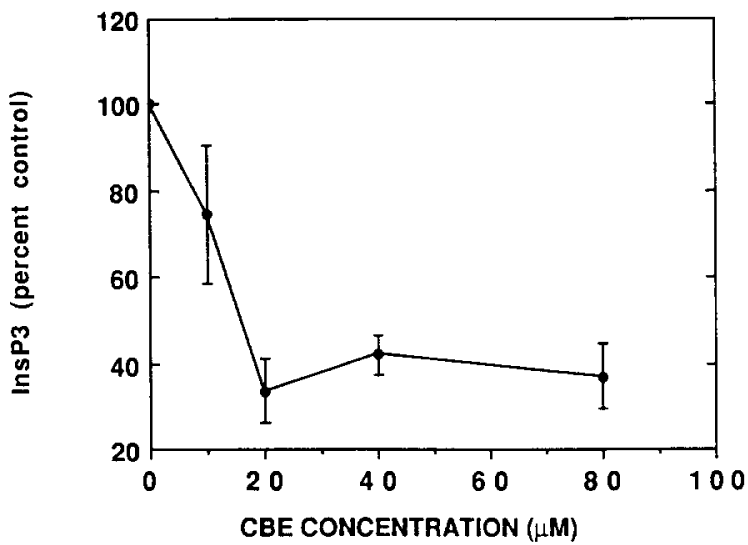

FIG. 4. Concentration-dependent effect of $\mathrm{CBE}$ on InsP3 formation by plasma membranes. MDCK cells were incubated for $24 \mathrm{~h}$ with varying concentrations of CBE. Membranes were isolated and hormone-stimulated InsP3 formation was determined as described in the legend to Fig. 3 . 

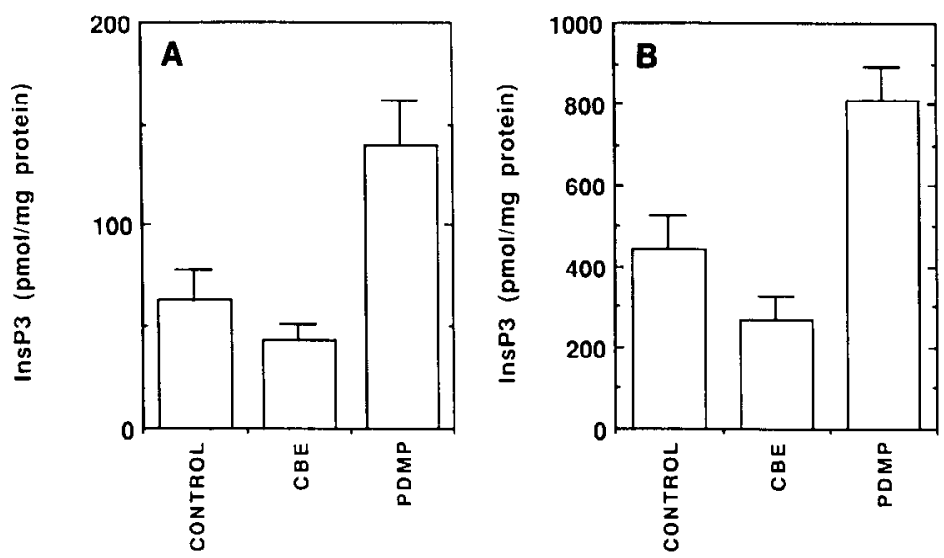

FIG. 5. InsP3 formation in the absence (A) or presence (B) of 5-phosphomonoesterase inhibition with 2,3-bisphosphoglycerate. MDCK cells were grown in the presence or absence of inhibitors and membranes were isolated as described under Materials and Methods. InsP3 formation in response to bradykinin and GTP $\gamma \mathrm{S}$ was determined following a 15-s incubation.

Phosphomonoesterase activity was effectively eliminated by the use of a magnesium-free buffer containing $10 \mathrm{mM}$ Hepes, $2 \mathrm{mM}$ EGTA, $424 \mu \mathrm{M} \mathrm{CaCl}_{2}, 115 \mathrm{mM} \mathrm{KCl}$, and 5 $\mathrm{mM} \mathrm{KH}{ }_{2} \mathrm{PO}_{4}, \mathrm{pH} 7.0$, and $2 \mathrm{mM}$ 2,3-bisphosphoglycerate. The comparative levels of InsP3 from membranes incubated with magnesium-containing buffer and magnesiumfree buffer with 2,3-bisphosphoglycerate are shown in Fig. 5. A three- to fivefold potentiation in InsP3 formation was observed under the latter conditions; however, the effects of altered cerebroside content persisted.

The ability of exogenously added GlcCer to modulate InsP3 formation was studied by exposing MDCK cells to GlcCer in liposomes containing phosphatidylcholine. Incorporation of GlcCer was established by the addition of GlcCer radiolabeled with $\left[{ }^{3} \mathrm{H}\right]$ palmitate (Fig. 6). Several products were labeled $24 \mathrm{~h}$ following the addition of the tritiated cerebroside. Most of the labeled products appeared to be the result of hydrolysis of the labeled cerebroside with incorporation of label into phosphatidylcholine and nonpolar lipidis, probably cholesterol esters. Alkaline methanolysis confirmed the incorporation of a significant amount of label into phosphatidylcholine.

The effect of exogenously added cerebroside on InsP3 formation was assessed (Fig. 7). CBE, which resulted in GlcCer accumulation, significantly lowered the rate of InsP3 formation. GlcCer alone decreased InsP3 formation slightly but significantly but, when added in combination with CBE, its effectiveness was potentiated by the glucosidase inhibitor. This effect was not observed with galactosylceramide.

The concentration dependence of exogenously added GlcCer was also determined (Fig. 8). GlcCer potentiated the inhibitory effects of CBE on InsP3 formation. The addition of $25 \mu \mathrm{g} / \mathrm{ml}$ of the cerebroside in the presence of CBE almost totally inhibited the formation of InsP3. Exposure of cells to phosphatidylcholine-containing liposomes alone was without effect.

\section{DISCUSSION}

Glycosphingolipids have been implicated as modulators of a variety of important cellular processes including growth (18), differentiation (19), and ionic transport (20). In addition, glycosphingolipids have been associated with

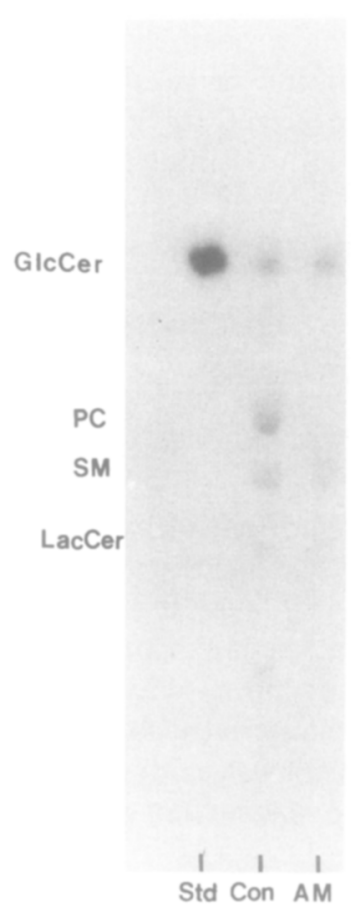

FIG. 6. The incorporation and metabolism of $\left[{ }^{3} \mathrm{H}\right] \mathrm{GlcCer}$ in MDCK cells. Liposomes containing radiolabeled cerebroside were added to the incubation media. Following $24 \mathrm{~h}$ the cells were washed with phosphatebuffered saline. Cell lipids were extracted and separated by TLC following no treatment (Con) or following alkaline methanolysis (AM). TLC separation utilized $\mathrm{CHCl}_{3}: \mathrm{MeOH}$ :water $60: 35: 8$ on a borax treated plate. Products were identified by fluororadiography. Phosphatidylcholine (PC), sphingomyelin (SM), lactosylceramide (LacCer), standard (Std). 


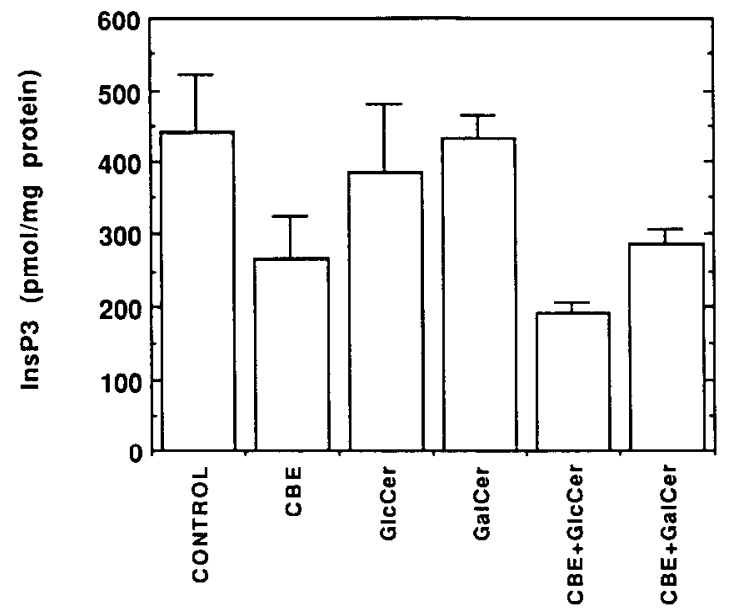

FIG. 7. Effects of exogenous cerebrosides on InsP3 formation. MDCK cells were grown in the presence of GlcCer- or galactosylceramide-containing liposomes with or without CBE. Cell membranes were isolated and InsP3 formation was determined as described above.

the modulation of signal transduction. This has been most extensively investigated with regard to tyrosine kinase activity $(2,21)$. However, the activities of other cellular kinases including protein kinase $\mathrm{C}(22,23)$ and calciumcalmodulin kinases (24) have been shown to be affected by exogenous addition of gangliosides. The activities of all three kinases have been demonstrated to modulate either InsP3 formation or catabolism. Recently, we reported a modulatory role for glucosphingolipids in the formation of bradykinin-stimulated inositol trisphosphate (4). Depletion of GlcCer with the synthase inhibitor PDMP resulted in time- and concentration-dependent increases in inositol trisphosphate formation. In the present study we extended these observations to include conditions of GlcCer excess.

The GlcCer content of MDCK cells was shown to increase in the presence of the $\beta$-glucosidase inhibitor CBE. A corresponding impairment of hormone-stimulated inositol trisphosphate formation was observed. This inhibition paralleled the concentration of CBE utilized as well as the duration of exposure of MDCK cells to the inhibitor. The incorporation of exogenously added GlcCer into MDCK cells was documented with the use of tritiated cerebroside radiolabeled in the fatty acid moiety. Although significant catabolism was evident, an impairment of inositol trisphosphate formation was still observed under these conditions.

In interpreting data based on the use of inhibitors, it is important to consider the possibility that the observed changes are the result of other, unknown effects of these agents. In the case of $\mathrm{CBE}$, several studies have found inhibition of $\beta$-glucosidase to be the only major effect (25 27).

These data are consistent with a role for GlcCer or of a related metabolite in mediating the formation of hor- mone-stimulated inositol trisphosphate. This conclusion is supported by the complementary nature of the glucosidase inhibitor on GlcCer levels and InsP3 formation when compared to the previous study evaluating GlcCerdepleted cells. Two questions arise from these observations. First, are the effects of altering GlcCer content on InsP3 formation the result of GlcCer alone or is the effect the result of changes in a related metabolite? Second, what is the mechanism responsible for the observed effects on InsP3 formation?

Regarding the first question, it is likely that GlcCer or a metabolite and not an anabolite mediates the effects on InsP3 formation. Although $\beta$-glucosidase and GlcCer synthase inhibition display opposite effects on InsP3 formation, they did not have complementary effects on ganglioside content (Table I). PDMP significantly lowered ganglioside GM3 labeling (4); CBE displayed no effects on GM3 even with prolonged incubation. Similarly, the observed increases in ceramide and sphingomyelin labeling were independent of the changes in GlcCer levels, suggesting that sphingomyelin or ceramide metabolism alone would be insufficient to account for the observed changes in InsP3 formation. The increased labeling of sphingomyelin and ceramide due to $\mathrm{CBE}$ and GlcCer accumulation may be the result of activation of protein kinase $\mathrm{C}$.

Both ganglioside GM3 (28) and sphingomyelin $(29,30)$ have been implicated in signaling and differentiation events. In addition, exposure to exogenous GlcCer resulted in a significant inhibition of InsP3 formation. However, in the absence of CBE, very little $\left[{ }^{3} \mathrm{H}\right] \mathrm{GlcCer}$ could be shown to be metabolized to higher glycosylation products

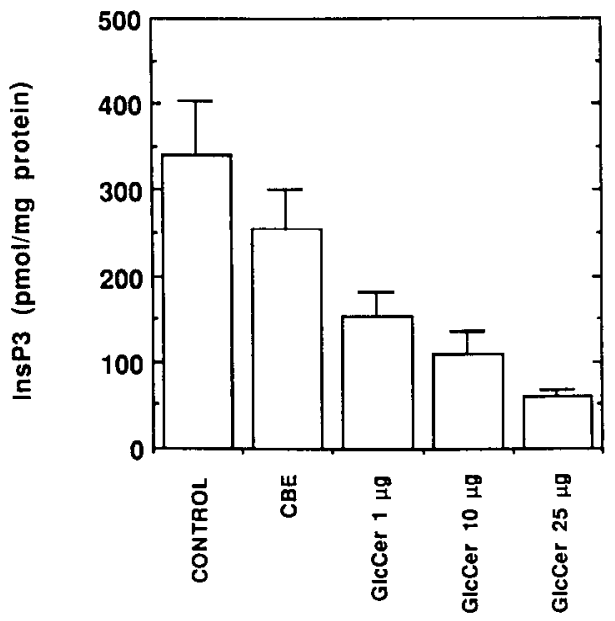

FIG. 8. Concentration dependence of exogenously added GlcCer on InsP3 formation. GlcCer-containing liposomes were prepared as described under Materials and Methods. All cells except for control cells were incubated with $20 \mu \mathrm{M}$ CBE and liposomes for $24 \mathrm{~h}$. Control cells were incubated with dioleoylphosphatidylcholine alone. The numbers refer to the GlcCer concentration in $\mu \mathrm{g} / \mathrm{ml}$ of medium. 
or to acidic glycosphingolipids due to the high degree of hydrolysis.

Regarding the second question, several potential mechanisms could explain the effect of GlcCer on InsP3 formation. These include the reported effects of glycosphingolipids on tyrosine kinase, protein kinase $\mathrm{C}$, or cAMP formation, with secondary effects on phospholipase $\mathrm{C}$ activity. Recent studies in MDCK cells have revealed that PDMP and CBE treatment are associated with inhibition and stimulation of protein kinase $\mathrm{C}$ activity, respectively (31). Altered protein kinase $\mathrm{C}$ activity may not only explain the mechanism for cerebroside-associated changes in phospholipase $\mathrm{C}$, but could also explain the observed increase in ceramide and sphingomyelin labeling (32).

The ability to modulate endogenous glucosphingolipid content should provide an important tool for defining the role of glycosphingolipids in cellular signaling events.

\section{REFERENCES}

1. Okada, Y., Radin, N. S., and Hakomori, S. (1988) FEBS Lett. 235, 25-29.

2. Felding-Habermann, B., Igarashi, Y., Fenderson, B. A., Park, L. S., Radin, N. S., Inokuchi, J., Strassmann, G., Handa, K., and Hakomori, S. (1990) Biochemistry 29, 6314-6322.

3. Inokuchi, J., Momosaki, K., Shimeno, H., Nagamatsu, A., and Radin, N. S. (1989) J. Cell Physiol. 141, 573-583.

4. Shayman, J. A., Mahdiyoun, S., Deshmukh, G., Barcelon, F., Inokuchi, J., and Radin, N. S. (1990) J. Biol. Chem. 265, 12,135-12,138.

5. Grabowski, G. A., Osiecki-Newman, K., Dinur, T., Fabbro, D., Legler, G., Gatt, S., and Desnick, R. J. (1986) J. Biol. Chem. 261, 82638269.

6. Grabowski, G. A., Osiecki-Newman, K., Dinur, T., Fabbro, D., Legler, G., Gatt, S., Desnick, R. J., Antonucci, F., Pizzolitto, S., Travaglini, M., Marrocco, G. F., Boscutti, G., Messa, M., Fogazzi, G. B., and Rivolta, E. (1989) Adv. Exp. Med. Biol. 252, 59-64.

7. Inokuchi, J., and Radin, N. S. (1987) J. Lipid Res. 28, 565-571.

8. Lee, K. J., Boyd, S. A., and Radin, N. S. (1985) Carbohydr. Res. $144,148-154$.
9. Radin, N. S. (1976) J. Lipid Res. 17, 290-293.

10. Taub, M., Chuman, L., Saier, M. H., Jr., and Sato, G. (1979) Proc. Natl. Acad. Sci. USA 76, 3338-3342.

11. Touchstone, J. C., Levin, S. S., Dobbins, M. F., Matthews, L., Beers, P. C., and Gabbe, S. G. (1983) Clin. Chem. 29, 1951-1954.

12. Hepler, J. R., and Harden, T. K. (1986) Biochem. J. 239, 141-146.

13. Bohlen, P., Stein, S., Dairman, W., and Udenfriend, S. (1973) Arch. Biochem. Biophys. 155, 213-220.

14. Shayman, J. A., and Wu, D. (1990) Am. J. Physiol. 258, F1282F1287.

15. Palmer, S., Hughes, K. T., Lee, D. Y., and Wakelam, M. J. (1989) Cell Signal. 1, 147-156.

16. Radin, N. S. (1972) in Methods in Enzymology (Ginsburg, V., Ed.), Vol. 28, pp. 300-306, Academic Press, San Diego.

17. Rana, R. S., Sekar, M. C., Hokin, L. E., and MacDonald, M. J, (1986) J. Biol. Chem. 261, 5237-5240.

18. Hakomori, S. (1981) Annu. Rev. Biochem. 50, 733-764.

19. Fenderson, B. A., Eddy, E. M., and Hakomori, S. (1990) Bioessays 12, 173-179.

20. Spiegel, S., Handler, J. S., and Fishman, P. H. (1986) J. Biol. Chem. 261, 15,755-15,760.

21. Bremer, E. G., Schlessinger, J., and Hakomori, S. (1986) J. Biol. Chem. 261, 2434-2440.

22. Kreutter, D., Kim, J. Y., Goldenring, J. R., Rasmussen, H., Ukomadu, C., DeLorenzo, R. J., and Yu, R. K. (1987) J. Biol. Chem. 262, 1633-1637.

23. Hannun, Y. A., and Bell, R. M. (1989) Science 243, 500-507.

24. Goldenring, J. R., Otis, L. C., Yu, R. K., and DeLorenzo, R. J. (1985) J. Neurochem. 44, 1229-1234.

25. Stephens, M. C., Bernatsky, A., Burachinsky, V., Legler, G., and Kanfer, J. N. (1978) J. Neurochem. 30, 1023-1027.

26. Newburg, D. S., Yatziv, S., McCluer, R. H., and Raghavan, S. (1986) Biochim. Biophys. Acta 877, 121-126.

27. Hara, A., and Radin, N. S. (1979) Biochim. Biophys. Acta 582, 423 433.

28. Hakomori, S. (1990) J. Biol. Chem. 265, 18,713-18,716.

29. Okazaki, T., Bell, R. M., and Hannun, Y. A. (1989) J. Biol. Chem. 264, 19,076-19,080.

30. Kolesnick, R. N. (1989) J. Biol. Chem. 264, 7617-7623.

31. Shayman, J. A., Deshmukh, G. D., Mahdiyoun, S., Thomas, T. P., Barcelon, F. S., and Radin, N. S. (1991) J. Biol. Chem. (in press).

32. Kolesnick, R. N. (1989) J. Biol. Chem. 264, 11,688-11,692. 